\title{
Fabrication of Biocompatible Potassium Sodium Niobate Piezoelectric Ceramic as an Electroactive Implant
}

\author{
Wei Chen ${ }^{1}$, Zunxiong Yu ${ }^{2}$, Jinshan Pang ${ }^{1, *}$, Peng Yu ${ }^{1}$, Guoxin Tan ${ }^{3}$ and Chengyun Ning ${ }^{1, *}$ \\ 1 School of Materials Science and Engineering, South China University of Technology, Guangzhou 510641, \\ China; chenweiofcw@163.com (W.C.); conan424683@live.com (P.Y.) \\ 2 Center for Human Tissues and Organs Degeneration, Shenzhen Institute of Advanced Technology, \\ Chinese Academy of Science, Shenzhen 518055, China; zunxiong.yu@gmail.com \\ 3 Institute of Chemical Engineering and Light Industry, Guangdong University of Technology, \\ Guangzhou 510006, China; tanguoxin@126.com \\ * Correspondence: pjsgd@163.com (J.P.); imcyning@scut.edu.cn (C.N.); \\ Tel.: +020-22236059 (J.P.); +020-82173002 (C.N.)
}

Academic Editor: Enrico Bernardo

Received: 12 December 2016; Accepted: 20 March 2017; Published: 26 March 2017

\begin{abstract}
The discovery of piezoelectricity in natural bone has attracted extensive research in emulating biological electricity for various tissue regeneration. Here, we carried out experiments to build biocompatible potassium sodium niobate $(\mathrm{KNN})$ ceramics. Then, influence substrate surface charges on bovine serum albumin (BSA) protein adsorption and cell proliferation on KNN ceramics surfaces was investigated. KNN ceramics with piezoelectric constant of $\sim 93 \mathrm{pC} / \mathrm{N}$ and relative density of $\sim 93 \%$ were fabricated. The adsorption of protein on the positive surfaces (Ps) and negative surfaces (Ns) of KNN ceramics with piezoelectric constant of $\sim 93 \mathrm{pC} / \mathrm{N}$ showed greater protein adsorption capacity than that on non-polarized surfaces (NPs). Biocompatibility of KNN ceramics was verified through cell culturing and live/dead cell staining of MC3T3. The cells experiment showed enhanced cell growth on the positive surfaces (Ps) and negative surfaces (Ns) compared to non-polarized surfaces (NPs). These results revealed that KNN ceramics had great potential to be used to understand the effect of surface potential on cells processes and would benefit future research in designing piezoelectric materials for tissue regeneration.
\end{abstract}

Keywords: potassium sodium niobate; electroactive; piezoelectric; biological; implant

\section{Introduction}

Recently, research interest has grown in exploiting electroactive bioceramic for hard tissue implantation. Electroactive bioceramic may induce improved biological responses due to the existence of the surface electric potential in bone remodeling cycle and the piezoelectricity of bone [1-4]. The electric potentials, which occur in bones under mechanical loading, are explained partially in terms of the piezoelectric properties of the collagen [5-9]. This inspires the use of an electro-active implant to improve healing and adaptation of the surrounding tissue, instead of external galvanism. Piezoelectric bioceramic could be an excellent alternative to hard tissue repair for its unique electroactivity [10-13].

Electroactive bioceramic, developed for implant, includes polarized hydroxyapatite (HA) [14] and piezoelectric bioceramic in general. Polarized HA works like a capacitor that charged by applying a high level electric field $(\mathrm{kV} / \mathrm{mm})$ at elevated temperature $\left(>200^{\circ} \mathrm{C}\right)[15-17]$. Polarized HA has, in some cases, a positive effect on biological responses, as several studies have reported that the polarized HA exhibited favorable bio-mineralization property and protein adsorption behavior [15,18-21]. However, its non-piezoelectricity and extremely low depolarization, current density below $200{ }^{\circ} \mathrm{C}$ [15] limited 
its application in environment in vivo. The above mentioned drawbacks can be avoided by using piezoelectric ceramic. Park et al. implanted piezoelectric barium titanate (BT) samples into canine femora and found that the longer the samples were implanted [22], the larger the voltage was produced, contributing to an increase in osseointegration. In a further study, Feng et al. found that bone growth aligned with the direction of poling using an implant of hydroxyapatite-barium titanate (HABT) composite [23]. Though it possesses passable bio-response according to the research, BT piezoelectric ceramic is difficult to apply because of its poor stability of temperature, and the cytotoxicity of barium and titanium ions cannot be ignored. At present, for potassium sodium niobate, researchers are more inclined to improving the piezoelectric properties by doping antimony (Sb), tantalum (Ta), bismuth (Bi), and other elements [24-27] with a view to replace lead zirconate titanate in industrial applications. Such doped potassium sodium niobate (KNN)-based piezoelectric ceramics have little potential in the field of implant materials due to the toxicity of the dopant elements, despite the high piezoelectric properties. Non-doped KNN has great potential in biomedical materials because of its good biocompatibility, good temperature stability (high Curie temperature), and much larger piezoelectric constant than natural bone. Thus, KNN piezoelectric ceramic could be competently used as a bone implant and the fabrication process should be investigated for biomedical application. KNN ceramic is usually fabricated by solid reaction route, which generally consists of ball milling and high temperature reaction process. Numerous fundamental studies on KNN mainly focused on the sintering temperature, which sensitively affects the physical and piezoelectric properties of ceramic for the composition segregation caused by the volatility of potassium and sodium at high temperature [28-31]. However, investigations, concerning about the effect of KNN powder fabrication that is prerequisite for controlling the physical and piezoelectric properties of ceramic, were insufficient [28,32-35].

The purpose of this paper was to fabricate an electroactive KNN piezoelectric ceramic by exploring milling time and calcination temperature and to investigate the influence of substrate surface charges on protein adsorption and cell proliferation on polarized surface compared to non-polarized surface (NPs) of KNN ceramic. In this study, we found that KNN powder fabrication was essential for controlling the piezoelectric and physical properties of KNN ceramic. Protein adsorption test with bovine serum albumin (BSA) as a normal protein model was exploited and the results revealed that both positive and negative polarized surfaces were more favorable to protein adsorption than the non-polarized samples. We also performed cells viability staining and cells proliferation experiments, the results of which revealed that KNN ceramics had the potential to be used to understand the role of surface potential on cell processes and great potential as an electroactive material in hard tissue regeneration.

\section{Results and Discussion}

Figure 1a shows the particle size distribution of the mixtures after ball milling for 4,8 and $16 \mathrm{~h}$ and bimodal distribution was observed. For $4 \mathrm{~h}$, in the main peak, the particle size distribution of mixtures powder ranged from 0.04 to $0.8 \mu \mathrm{m}$, when ball milling time was extended to $8 \mathrm{~h}$, the particle size was reduced to between 0.03 and $0.3 \mu \mathrm{m}$. However, the size of the particles becomes larger, between 0.05 and $0.7 \mu \mathrm{m}$, when ball milling time was prolonged to $16 \mathrm{~h}$. The above results could be explained that insufficient ball milling time led to larger particle size, while excess ball milling time would produce similar result because of reuniting. As for the diameter from 2 to $20 \mu \mathrm{m}$, it was a bubble due to ultrasonic dispersion, which was indirectly demonstrated by scanning electron microscopy (SEM) images of the KNN particles in Figure 2. Ball milling for $8 \mathrm{~h}$ was sufficient according to this study, which corresponded to the particle size distribution mainly from 30 to $300 \mathrm{~nm}$. 

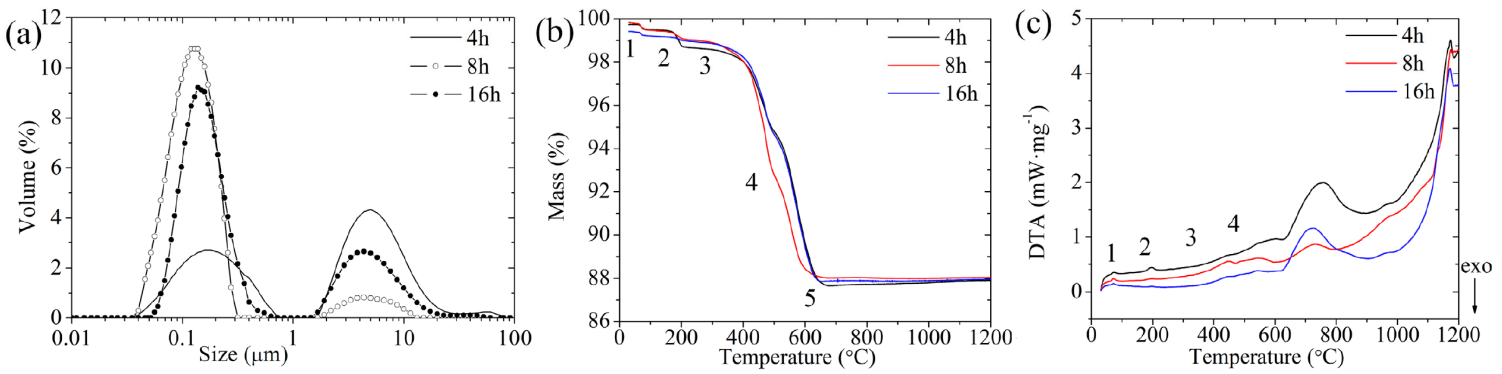

Figure 1. Particle size distribution, thermal gravimetric (TG), and differential thermal analysis (DTA) curves of the mixtures ball-milled for different time. (a) Particle size distribution of the mixtures ball-milled for 4, 8 and $16 \mathrm{~h}$, respectively; (b) TG and (c) DTA curves of the mixtures ball-milled for 4, 8 and $16 \mathrm{~h}$. The insert of 1,2,3,4 and 5 in Figure $1 \mathrm{~b}$ show weight loss peaks associated with endothermic peaks of inserted 1,2,3 and 4 in Figure 1c.
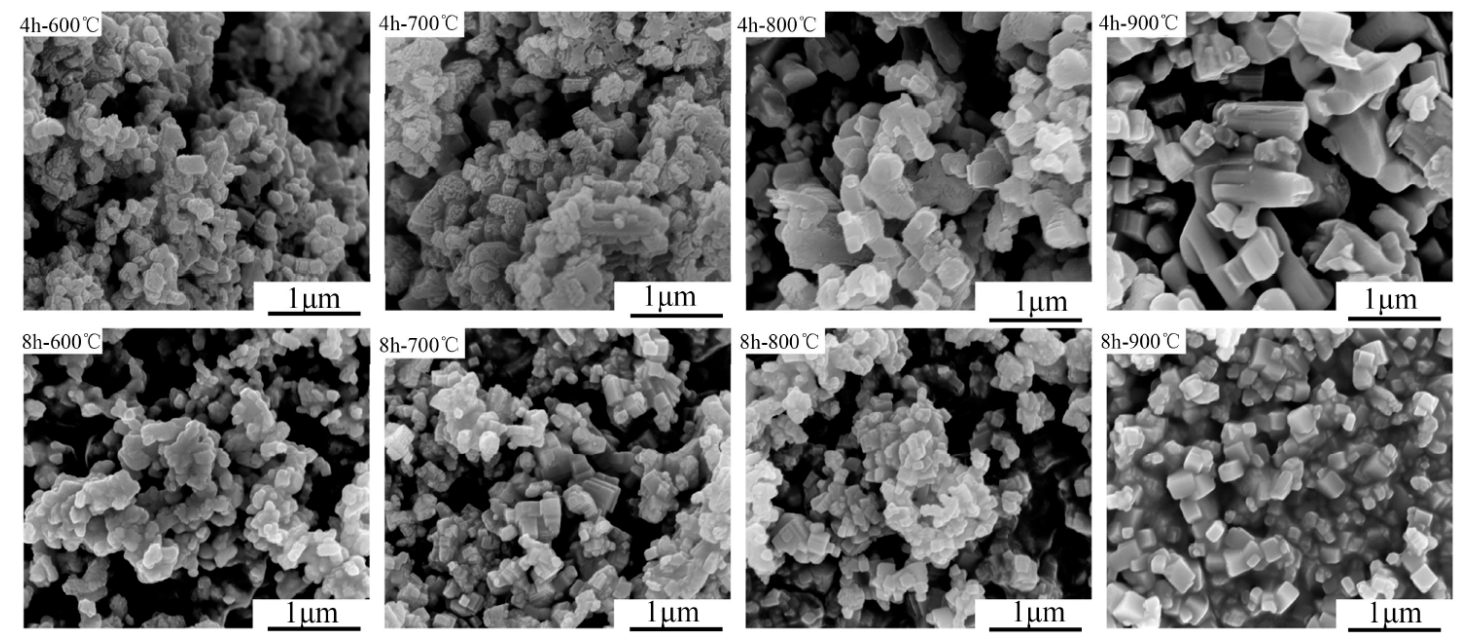

Figure 2. Scanning electron microscopy (SEM) images of mixture powder calcined at different temperature from 600 to $900{ }^{\circ} \mathrm{C}$ after ball milled for 4 and $8 \mathrm{~h}$, respectively. When ball-milled for $8 \mathrm{~h}$ under the same temperature, particle size was smaller and more uniform.

Figure $1 \mathrm{~b}, \mathrm{c}$ shows the results of the TG/DTA for the raw mixtures. The samples experienced a mass loss between $11.30 \%$ and $11.86 \%$ upon heating to $700{ }^{\circ} \mathrm{C}$. According to thermal gravimetric (TG) and differential thermal analysis (DTA) curves of Figure 1b,c, four weight loss peaks can be observed on the TG curve (Figure 1b, at 82, 185, 362, and $491^{\circ} \mathrm{C}$ ) associated with endothermic peaks in Figure 1c. The first weight loss occurring at $82{ }^{\circ} \mathrm{C}$ is attributed to the removal of absorbed moisture water. The weight loss peak at $185^{\circ} \mathrm{C}$ is relevant to simultaneous losses of $\mathrm{H}_{2} \mathrm{O}$ and $\mathrm{CO}_{2}$ [36], which comes from the decomposition of $\mathrm{AHCO}_{3}$ to $\mathrm{A}_{2} \mathrm{CO}_{3}\left(\mathrm{~A}\right.$ is $\mathrm{K}^{+}$or $\left.\mathrm{Na}^{+}\right)$[37]. The main weight losses occurred in a narrow temperature range between 400 and $600{ }^{\circ} \mathrm{C}$, corresponding to the $\mathrm{CO}_{2}$ losses. The region of about $500-680^{\circ} \mathrm{C}$ is due to the formation of the perovskite structure with a maximum mass loss at $650^{\circ} \mathrm{C}$. It was also observed from the TG curves that the appropriate calcination temperature is about $700{ }^{\circ} \mathrm{C}$.

Figure 2 showed the micro-morphology of mixture powder calcined at 600 to $900{ }^{\circ} \mathrm{C}$ after ball milled for 4 and $8 \mathrm{~h}$. Despite its smaller particle size, a considerable part of impurities were still observed in the mixtures calcined at $600{ }^{\circ} \mathrm{C}$ from the result of Figure 3 . With temperature increasing from 700 to $900{ }^{\circ} \mathrm{C}$, the particle changed from random to regular. Ball-milled for $4 \mathrm{~h}$ and calcined at 600,700 and $800^{\circ} \mathrm{C}$, the powder mixtures were almost random, while regular shape particle appeared at $900{ }^{\circ} \mathrm{C}$. It could be explained by that the higher the calcination temperature, the bigger the KNN crystal grew for the $2 \mathrm{~h}$ compress time in this study. However, the enlarged particle was adverse to 
densification of the sintering process [30]. When ball-milled for $8 \mathrm{~h}$ and under the same temperature, the results showed evident uniformity in the particle size of powder mixtures. It could only be concluded that the mixtures milled for $8 \mathrm{~h}$ were advantageous to control the particle size of calcined powder. However, it is arbitrary to decide which was optimal. The appropriate fabrication process including milling time or calcination temperature was decided by the final piezoelectric and physical properties of the ceramic, as showed in Figure 4.

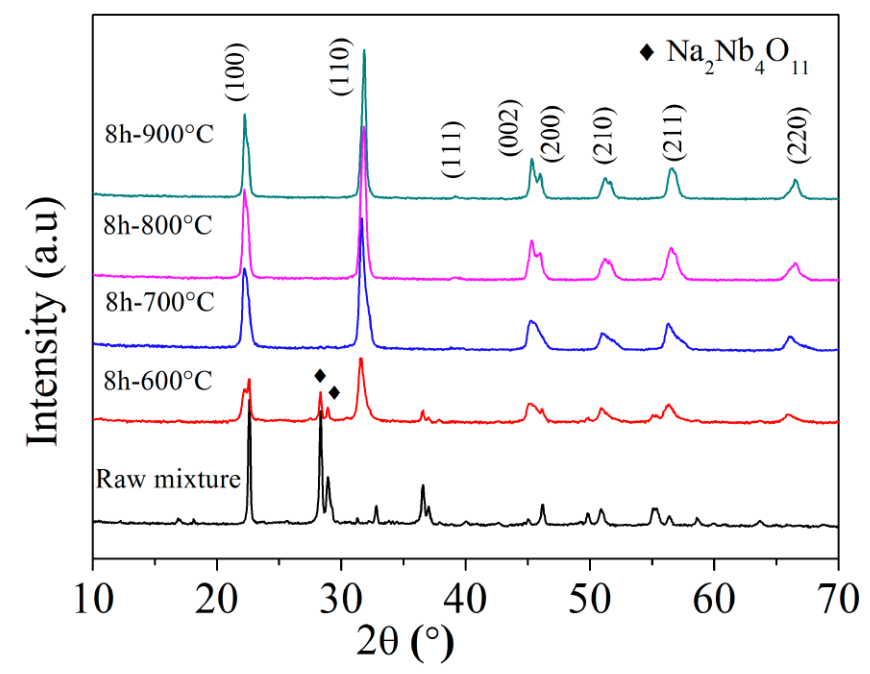

Figure 3. X-ray diffraction (XRD) patterns of raw material and mixture powder calcined at different temperature from 600 to $900{ }^{\circ} \mathrm{C}$ after ball milling for $8 \mathrm{~h}$.
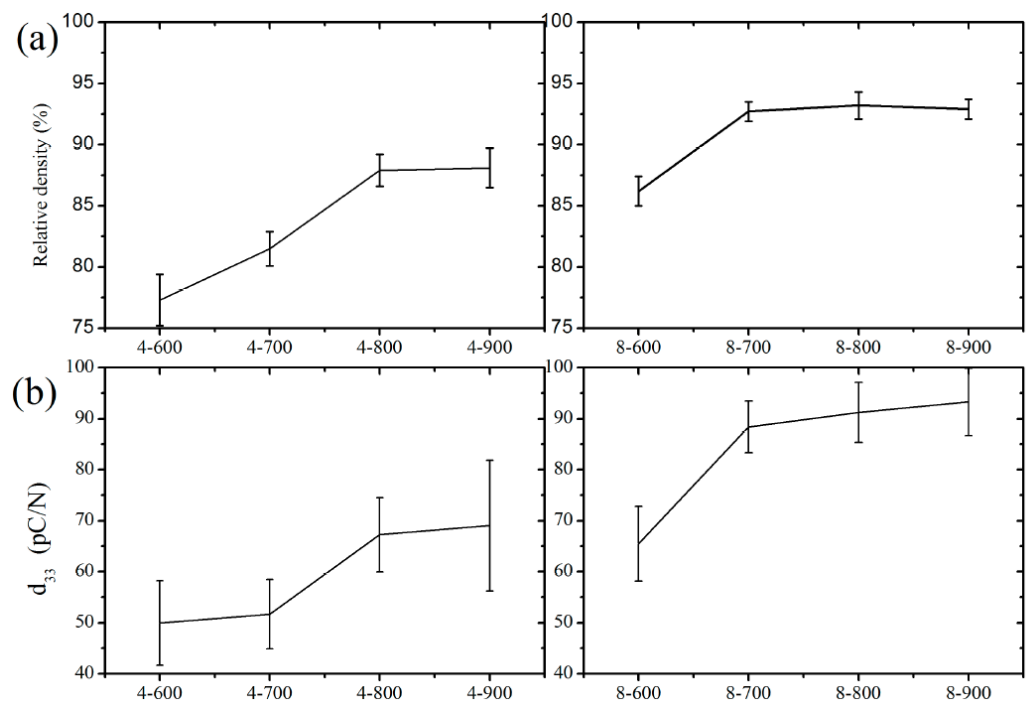

Figure 4. Relative density and piezoelectric constant $\left(d_{33}\right)$ of the polarized ceramic prepared from corresponding potassium sodium niobate $(\mathrm{KNN})$ powder. The relationship between relative density (a); piezoelectric constant $\left(\mathrm{d}_{33}\right)(\mathbf{b})$ and calcination temperature (from 600 to $900{ }^{\circ} \mathrm{C}$ ) after ball-milled for 4 and $8 \mathrm{~h}$, respectively.

The crystal structure of sample powder was verified by X-ray diffraction (XRD), as shown in Figure 3. When mixtures calcined at $600{ }^{\circ} \mathrm{C}$, it could be seen that the peak of calcined powder had weaken a lot comparing to raw material, indicating that phase transformation had occurred, but incompletely. $\mathrm{Na}_{2} \mathrm{Nb}_{4} \mathrm{O}_{11}$ (PDF\#20-1145) was identified according to the broad peak in the $2 \theta$ from $20^{\circ}$ to $30^{\circ}$ [38]. However, when the temperature rose to $700{ }^{\circ} \mathrm{C}$, it was evident that the peaks of 
raw materials disappeared, which was consistent with the TG-DTA result as showed in Figure 1c since complete reaction temperature of the " $8 \mathrm{~h}$ " sample was nearly $700{ }^{\circ} \mathrm{C}$. It was easy to see the diffraction patterns corresponded to a typical perovskite phase and the crystallographic indexing was based on the perovskite type, both for orthorhombic structure (Space Group: Amm2) and tetragonal structure (Space Group: P4mm) by using Jade 5.0 Software (MDI, Livermore, CA, USA, 2008). Besides, after calculating the ratio $\left(\mathrm{I}_{(002)} / \mathrm{I}_{(200)}\right)$, which was about 1.496 between $1 / 2$ and 2 , the coexistence of orthorhombic and tetragonal phase was also defined [39]. Going on raising the temperature, the phase of the mixtures had changed very little, which implied stabilization coexistence between a tetragonal symmetry $(\mathrm{T})$ and an orthorhombic symmetry $(\mathrm{O})$ as a result of the effect of polymorphic phase boundary (PPB) in the perovskite [40]. As can be seen from Table 1, the calculated lattice parameters of both tetragonal symmetry $(\mathrm{T})$ and orthorhombic symmetry $(\mathrm{O})$ tended to be stable from 700 to $900{ }^{\circ} \mathrm{C}$. It meant complete crystal structure were obtained at $700{ }^{\circ} \mathrm{C}$.

Table 1. Structural parameters of the powder determined by Jade 5.0 software at different calcination temperature.

\begin{tabular}{clllll}
\hline \multirow{2}{*}{$\begin{array}{c}\text { Temperature } \\
\left({ }^{\circ} \mathbf{C}\right)\end{array}$} & \multicolumn{3}{c}{ Lattice Parameters of the O Phase } & \multicolumn{2}{c}{ Lattice Parameters of the T Phase } \\
\cline { 2 - 6 } & $\boldsymbol{a}(\AA)$ & $\boldsymbol{b}(\AA)$ & $\boldsymbol{c}(\AA)$ & $\boldsymbol{a}=\boldsymbol{b}(\AA)$ & $\boldsymbol{c}(\AA)$ \\
\hline 700 & 3.9722 & 5.6297 & 5.7667 & 3.9969 & 3.9889 \\
800 & 3.9743 & 5.6329 & 5.7696 & 3.9874 & 4.0228 \\
900 & 3.9774 & 5.6369 & 5.7685 & 3.9904 & 4.0054 \\
\hline
\end{tabular}

As shown in Figure 4, the obtained relative density and piezoelectric constant of KNN ball-milled for $8 \mathrm{~h}$ were generally higher than that for $4 \mathrm{~h}$. Piezoelectric constant $\left(\mathrm{d}_{33}\right)$ of KNN disk samples corresponding to the calcined powder were exhibited in Figure $4 \mathrm{~b}$. The obtained $d_{33}$ constant of $\mathrm{KNN}$ ball-milled for $8 \mathrm{~h}$ and calcined at $700{ }^{\circ} \mathrm{C}$ reached about $93 \mathrm{pC} / \mathrm{N}$ via regulating the powder preparation before sintering. Under the condition of ball-milled for $4 \mathrm{~h}$, the obvious improvement of the relative density and piezoelectric constant $\left(\mathrm{d}_{33}\right)$ occurred from 700 to $800{ }^{\circ} \mathrm{C}$ (left in Figure $4 \mathrm{a}, \mathrm{b}$ ), while under the condition of ball-milled for $8 \mathrm{~h}$, the mutation happened from 600 to $700{ }^{\circ} \mathrm{C}$ (right in Figure $4 a, b)$. The results could be concluded that the KNN grains were not formed effectively when the ball milling time was not enough and the particle size was too large, so the mixture powder needed to be melted at a higher temperature to form KNN grains. When the milling time was $8 \mathrm{~h}$, the particle size is relatively uniform and fine, it was possible to react at $700{ }^{\circ} \mathrm{C}$, which was consistent with the results of particle size distribution and the TG-DTA results of Figure 1a,c. According to Figure 2, the XRD results showed that three kinds of mixtures were supposed to react incompletely at $600{ }^{\circ} \mathrm{C}$. Though the formation of perovskite structure was observed, it contained other phase of $\mathrm{Na}_{2} \mathrm{Nb}_{4} \mathrm{O}_{11}$ (PDF\#20-1145) [38], leading to a low relative density of the ceramic and a decrease of the corresponding piezoelectric constant. Compared with piezoelectric ceramics used in industrial applications, $93 \mathrm{pC} / \mathrm{N}$ is small, but it is large enough for application in the piezoelectric bone implants [8]. These results indicated that the calcined temperature should be $700{ }^{\circ} \mathrm{C}$ at least and the ball milling time of the mixtures should be up to $8 \mathrm{~h}$ to keep capable piezoelectric properties.

$\mathrm{KNN}$ ceramics with piezoelectric constant of $93 \mathrm{pC} / \mathrm{N}$ prepared by sintering the die-pressed $8 \mathrm{~h}-700^{\circ} \mathrm{C}$ samples in air at $1050{ }^{\circ} \mathrm{C}$ for $2 \mathrm{~h}$, were chosen for SEM observation, phase inspection, surface potential study, and BSA protein adsorption testing. It showed the surface microstructure and element composition seen in Figure 5a. There were small pores between the grains, which are favorable for the contact of the material with the surrounding body fluids [41]. The XRD pattern in Figure $5 \mathrm{~b}$ revealed that KNN ceramic was in perovskite phase with orthorhombic-tetragonal phase coexistences, and the relative volume fractions $(\%)$ of the $\mathrm{T}\left(\mathrm{V}_{\mathrm{T}}\right)$ and $\mathrm{O}\left(\mathrm{V}_{\mathrm{O}}\right)$ of the two-phase coexistence in this system were calculated as $39 \pm 3$ and $61 \pm 5$, respectively, from the following equations [25,42]:

$$
\mathrm{V}_{\mathrm{T}}=\left[\mathrm{I}_{(002)_{\mathrm{T}}}+\mathrm{I}_{(200)_{\mathrm{T}}}\right] /\left[\mathrm{I}_{(002)_{\mathrm{T}}}+\mathrm{I}_{(200)_{\mathrm{T}}}+\mathrm{I}_{(022)_{\mathrm{O}}}+\mathrm{I}_{(200)_{\mathrm{O}}}\right] \text {, }
$$




$$
\mathrm{V}_{\mathrm{O}}=\left[\mathrm{I}_{(022)_{\mathrm{O}}}+\mathrm{I}_{(200)_{\mathrm{O}}}\right] /\left[\mathrm{I}_{(002)_{\mathrm{T}}}+\mathrm{I}_{(200)_{\mathrm{T}}}+\mathrm{I}_{(022)_{\mathrm{O}}}+\mathrm{I}_{(200)_{\mathrm{O}}}\right]
$$

where $\mathrm{I}_{(002)_{\mathrm{T}}}, \mathrm{I}_{(200)_{\mathrm{T}}}, \mathrm{I}_{(022)_{\mathrm{O}}}$ and $\mathrm{I}_{(200)_{\mathrm{O}}}$ are the integrated intensities of the tetragonal (002) and (200) peaks, orthorhombic (022) and (200) peaks.

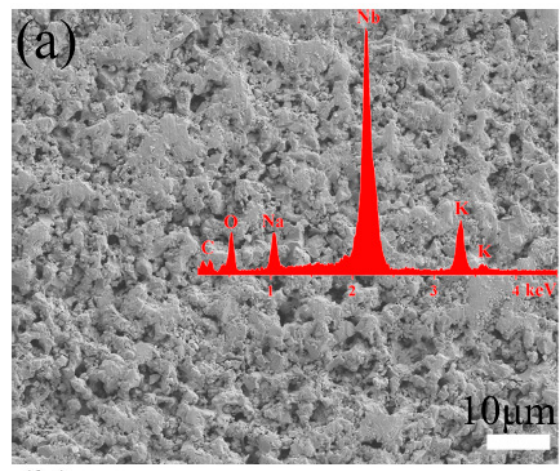

(b)

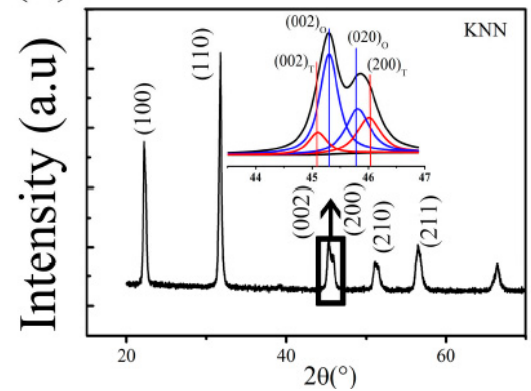

(c)
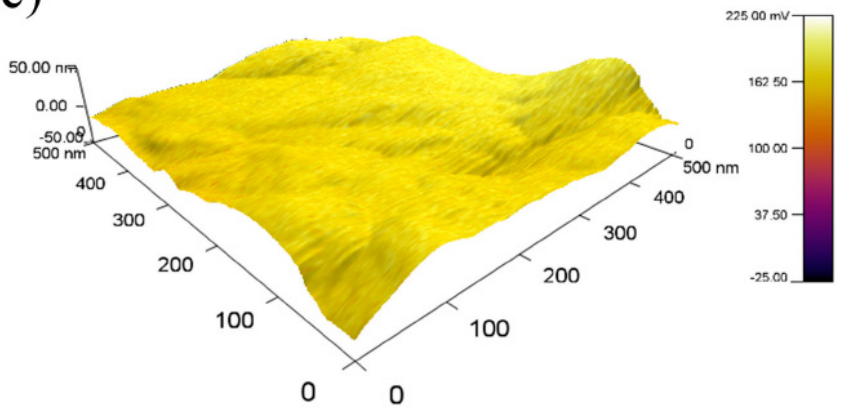

(d)

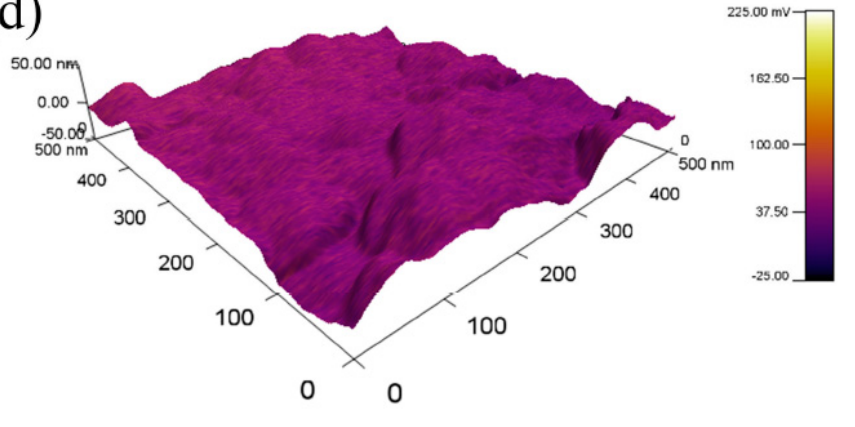

(e)

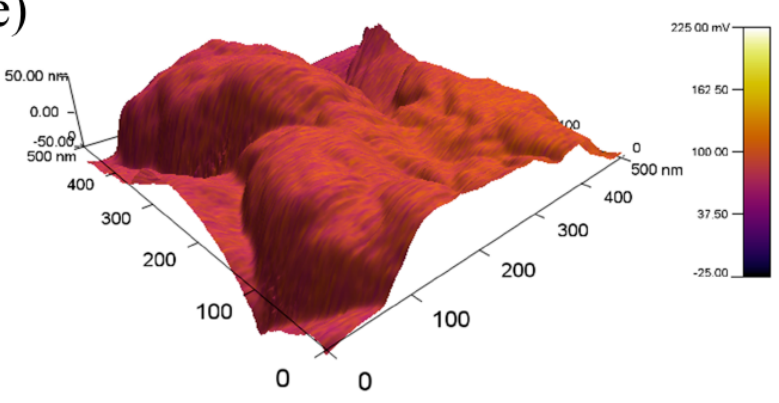

(f)

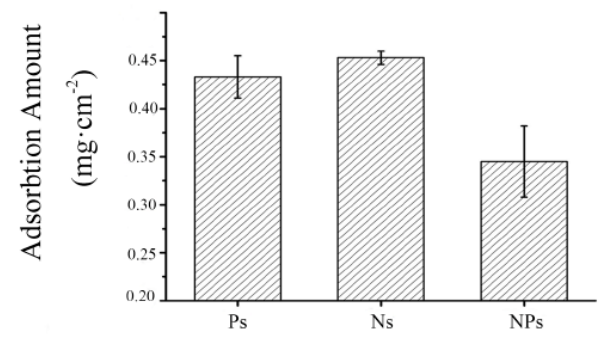

Figure 5. (a) SEM image of KNN ceramic with energy-dispersive X-ray spectroscopy (EDS) results inserted; (b) XRD pattern of the KNN ceramic including the insert of detail in the $2 \theta$ from $44.2^{\circ}$ to $47^{\circ}$, which were fitted to the sum of four peaks indexed as two tetragonal peaks (in red) plus two orthorhombic peaks (in blue) of the perovskite phase; the surface potential by scanning Kelvin probe microscopy (SKPM) and protein adsorption behavior on three different KNN ceramic surfaces: (c) on positive surface (Ps); (d) on negative surface (Ns) and (e) on non-polarized surface (NPs); (f) the results of bovine serum albumin (BSA) protein adsorption. 
As can be seen in Figure $5 c-e$, the surface potential of Ps, Ns, and NPs were quite different. According to the measurement and calculation by collecting the data from three randomly selected areas $(500 \mathrm{~nm} \times 500 \mathrm{~nm})$ on $\mathrm{KNN}$ ceramics, the average value of surface potential were $171 \pm 9,49 \pm 5$, and $90 \pm 8 \mathrm{mV}$ in air, respectively. The potential of three KNN surfaces increased from negative surface (Ns), non-polarized surface (NPs) to positive surface (Ps) successively.

The amount of BSA adsorption on positive surface (Ps) and negative surface (Ns) were higher than that on non-polarized surface (NPs) in Figure 5f. In general, each protein or amino acid has an isoelectric point (the $\mathrm{pH}$ of solution) where they exhibited an electrically neutral state. When the $\mathrm{pH}$ of solution was higher or lower than isoelectric point of a protein or amino acid, it displayed negative or positive in solution, respectively. The isoelectric point of BSA protein is 4.7, so BSA protein is negative when dissolved in phosphate buffer solution (PBS) $(\mathrm{pH}=7.4)$ [15]. In this work, both positive and negative surfaces exhibited enhanced protein adsorption than non-polarized surfaces, the result of which could be explained in term of ion crowding in the electric double layer [43-45], whereby the crowding of counterions dominates screening. When KNN were immersed into BSA solution, negative BSA proteins were selectively adsorbed on positive KNN surface. While on negative KNN surface, cations $\left(\mathrm{K}^{+}, \mathrm{Na}^{+}\right)$were closely attracted, leading to the presence of positively charged ion layer, then absorbed negative BSA. In addition, it was also reported that proteins would experience conformational changes when absorbed onto solid surface [46,47], which affected the amount of adsorption. Although understanding about the conformational changes is not enough, it has been demonstrated that surface charge has a great impact on this process [48,49]. The adsorption mechanism can refer to Figure 6, a schematic illustration for cell proliferation. In this study, BSA proteins were more attracted to the charged KNN surfaces just like anion in the electric double layer compared to uncharged KNN surfaces, as our results showed.

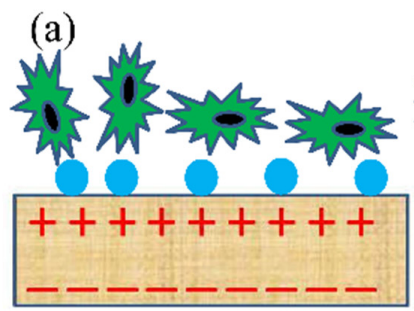

Positive KNN (b)

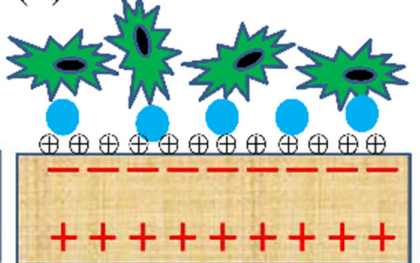

Negative KNN (c)

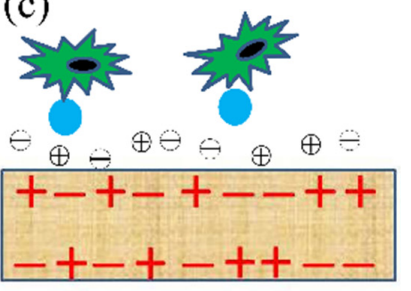

Non-polaried KNN

$=\quad$ Anions $\left(\mathrm{Cl}^{-}, \mathrm{HPO}_{4}{ }^{2-}, \mathrm{OH}^{-}, \mathrm{PO}_{4}{ }^{3-}\right)$

$\oplus$ Cations $\left(\mathrm{Ca}^{2-}, \mathrm{Mg}^{2+}, \mathrm{K}^{+}, \mathrm{Na}^{+}\right)$

Protein \& animo acid

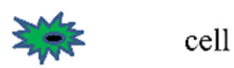

Figure 6. Schematic drawing of the interaction among three different surfaces of KNN and the environmental species. (a) On the positive KNN, anions and negatively charged proteins are actively adsorbed, forming a protein layer; (b) On the negative $\mathrm{KNN}$, cations, particularly $\mathrm{Ca}^{2+}$, are selectively adsorbed ,leading to the presence of positively charged ion layer, which in turn promote prot ein adsorption and proliferation cells on this surface; (c) On non-polarized KNN surface, inorganic ions, amino acids and proteins float and attach to non-polarized KNN.

To assess cell viability, MC3T3-E1 osteoblasts were seeded on KNN ceramics with piezoelectric constant of $93 \mathrm{pC} / \mathrm{N}$ and after $24 \mathrm{~h}$ were stained with calcein for live (in green) and with propidium iodide for dead (in red). The fact that only a few dead cells (stained in red) were observed showed that the synthetic KNN ceramics did not cause damage to cells, namely they were non-toxic, whether they were polarized or not. To further study their biocompatibility, cells proliferation experiment was performed. The study on the proliferation (Figure 7d) of MC3T3-E1 osteoblasts using cell counting kit 8 (CCK-8) assays revealed that Ps and Ns ceramics promoted cell growth more significantly than NPs samples for approximately seven days. Although BSA was not directly related to cell growth, the 
mechanism of BSA protein adsorption can also be applied to the cell proliferation. The culture medium mimicking the physiological environment contained different chemicals that had the same opportunity to contact and to be adsorbed on the surface of KNN ceramic. However, the charged groups in the medium can be repulsed or attracted by the surface charge of KNN. An explanation was made in term of ion crowding in the electric double layer [43-45], whereby the crowding of counterions dominates screening. When KNN were immersed into cell culture medium, since most proteins are negatively charged under physiological conditions, as a result of an isoelectric point less than $6[50,51]$, negative protein were selectively adsorbed on positive $\mathrm{KNN}$ surface, forming a protein layer that contributes to cell adhesion [52] (Figure 6a). While on negative KNN surface, cations including $\mathrm{Ca}^{2+}$ counter-ions, which is considered to promote osteoblast cell adhesion by attracting negatively charged proteins from cell medium [16] and by supplying $\mathrm{Ca}^{2+}$ to binding sites in transmembrane proteins responsible for cell adhesion and proliferation [53], were closely attracted, contributing to the adhesion and proliferation of cells on this surface (Figure 6b). On non-polarized KNN surface, inorganic ions, amino acids and proteins float and attach to non-polarized KNN assuming that the non-polarized surface was neutral, compared to the negative surface and the positive surface (Figure 6c). In addition, considering that cell size $(10-20 \mu \mathrm{m})$ is bigger than the positive or negative regions (several hundred nanometers) [54] in non-polarized KNN, the absorption due to electrostatic effects was more difficulty. The biocompatible KNN piezoelectric ceramics obtained in this study can be an ideal candidate model to investigate the interaction between surface charge and multi-potential cells such as stem cells in the future. The results from cell viability and proliferation assay (shown in Figure 7a-d) clearly showed the great potential of polarized KNN ceramics as a new biomaterial with electroactivity for bone tissue regeneration.
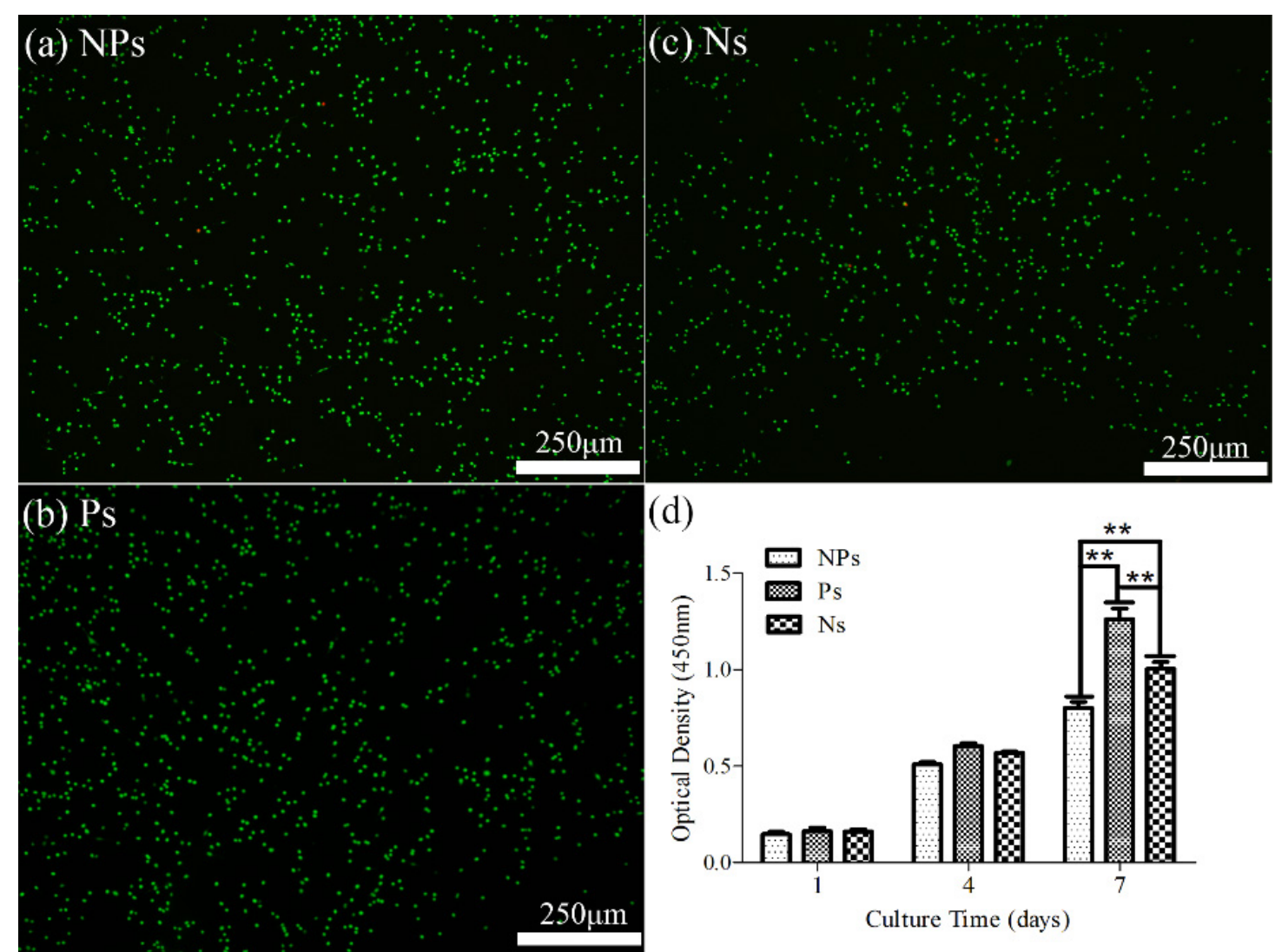

(d)

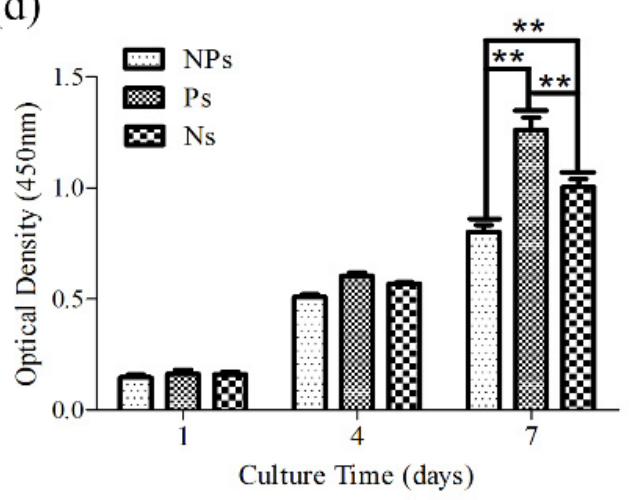

Figure 7. Cell viability on the surfaces of KNN piezoelectric ceramics: Calcein AM to detect live cells, propidium iodide to detect dead cells. (a) non-polarized surfaces (NPs); (b) positive surfaces (Ps) and (c) negative surfaces (Ns); (d) Cell proliferation on NPs, Ps and Ns was determined by CCK-8 assay on days 1, 4 and 7 days. The ${ }^{* *}$ indicated significant difference $(p<0.01)$. 


\section{Materials and Methods}

\subsection{Samples Preparation}

The KNN piezoelectric ceramic powder was synthesized by solid state reaction using the raw materials of sodium carbonate $\left(\mathrm{Na}_{2} \mathrm{CO}_{3}, 99.8 \%\right.$, Sinopharm Chemical Reagent Co. Ltd., Shanghai, China), potassium carbonate $\left(\mathrm{K}_{2} \mathrm{CO} 3,99.0 \%\right.$, Sinopharm Chemical Reagent Co. Ltd., Shanghai, China), and niobium oxide $\left(\mathrm{Nb}_{2} \mathrm{O}_{5}, 99.9 \%\right.$, Shanghai Aladdin, Shanghai, China) at the mole ratio of $\mathrm{r}(\mathrm{K}: \mathrm{Na}: \mathrm{Nb})=0.5: 0.5: 1$. After drying at $120^{\circ} \mathrm{C}$ for $5 \mathrm{~h}$, the raw materials were weighed and added to a Teflon bottle along with agate balls of $6 \mathrm{~mm}$ and $10 \mathrm{~mm}$ in diameter. The ratio of powder mixtures to balls to liquid was approximately 1:4:4 by mass. Then the mixtures were ball-milled by planetary using ethanol as medium for 4,8 and $16 \mathrm{~h}$, respectively. The dried mixtures were calcined in an alumina crucible at different temperature of $600,700,800$, and $900{ }^{\circ} \mathrm{C}$ for $2 \mathrm{~h}$, respectively. Adding 8 wt $\%$ of polyvinyl alcohol as binder, the calcined powder mixtures were then die-pressed into discs (diameter $10 \mathrm{~mm}$, thickness $3 \mathrm{~mm}$ ) under $150 \mathrm{MPa}$ without second ball milling and sintered in air at $1050{ }^{\circ} \mathrm{C}$ for $2 \mathrm{~h}$ in a loosely-covered $\mathrm{Al}_{2} \mathrm{O}_{3}$ crucible.

\subsection{Poling and Protein Adsorption}

After gold electrode was sprayed on both surfaces, KNN disks were poled at the electric field of $2.5 \mathrm{kV} / \mathrm{mm}$ under $100{ }^{\circ} \mathrm{C}$ in silicone oil for $15 \mathrm{~min}$ using piezoelectric polarization device (HYJH-3-4, Huiyuan Automation Equipment Co., Ltd., Xianyang, China). After polishing and ultrasonic cleaning, the disks were immersed into the phosphate buffer solution (PBS, $1 \times$, Gibco, Carlsbad, CA, USA) for $24 \mathrm{~h}$ and then wiped up the residual liquid on both surfaces. After drying, differently polarized KNN disks with a diameter of $10 \mathrm{~mm}$ were immersed $1 \mathrm{~mL}$ of protein solution $(1 \mathrm{mg} / \mathrm{mL})$ and incubated at $37^{\circ} \mathrm{C}$ for $10 \mathrm{~h}$ with the opposite surface sticking to the bottom of 24 -well plate. Then the protein solution was removed, followed by transferring the disks to a new plate. The amount of the absorbed protein on KNN ceramics were determined by bicinchoninic acid (BCA) assay. The protein concentration of remnant solution was tested $562 \mathrm{~nm}$ by microplate reader (Thermo Scientific, Waltham, MA, USA). The experiment was repeated at least three times and a mean value was calculated.

\subsection{Live/Dead Cell Staining and Proliferation Assay}

Positive polarized, negative polarized, and non-polarized KNN ceramics with piezoelectric constant of $93 \mathrm{pC} / \mathrm{N}$ were sterilized by autoclaving at $120{ }^{\circ} \mathrm{C}$ for $30 \mathrm{~min}$ and then placed in 48 -well plates. MC3T3-E1 osteoblasts were cultured in $\alpha$-modified minimum essential medium $(\alpha-\mathrm{MEM})$ supplemented with $10 \%$ fetal bovine serum (FBS) in a humidified incubator at $37{ }^{\circ} \mathrm{C}$ and $5 \% \mathrm{CO}_{2}$. MC3T3-E1 osteoblasts were seed on the specimens at $2 \times 10^{4}$ cells $/ \mathrm{mL}$ for live/dead cell staining for $24 \mathrm{~h}$ and cell proliferation for 1, 4 and 7 days, respectively. The medium was changed every two days for the duration of the experiment. Dulbecco's Phosphate Buffered Saline (DPBS) solutions supplemented with $2 \mathrm{~mL}(1 \mathrm{mg} / \mathrm{mL})$ calcein-AM and $2 \mathrm{~mL}(1 \mathrm{mg} / \mathrm{mL})$ propidium iodide was used for live and dead cells staining, respectively. After incubation for $40 \mathrm{~min}$ at $37^{\circ} \mathrm{C}$ and $5 \% \mathrm{CO}_{2}$, the samples were washed with DPBS and were imaged using inverted fluorescence microscope (Shinjuku, Tokyo, Japan). Cell Counting Kit-8 (CCK-8) assay was used to evaluate cell proliferation at 1, 4, and 7 days.

\subsection{Characterizations}

Particle size distribution of ball-milled mixture was determined by laser particle analyzer (LPA) (Mastersizer 2000, Malvern, England) using dehydrated ethanol as the solvent. Thermal gravimetric (TG) and differential thermal analysis (DTA) (NETZSCH-STA449C, Bavaria, Germany) were used for characterizing the thermo properties of the mixtures, with a heating rate of $5 \mathrm{~K} / \mathrm{min}$ from room temperature to $1200^{\circ} \mathrm{C}$. The compositions and morphology of calcined powder were examined by X-Ray Diffraction (XRD, X'Pert Pro, PANalytical, Amsterdam, the Netherlands) and scanning electron microscopy (Evo 50, Zeiss, Oberkochen, Germany), respectively. Jade 5.0 program was used to analyze 
X-ray diffraction data. Density of the ceramic was measured using Archimedes principle. $\mathrm{d}_{33}$ meter (YE2730A, YuTian Technology Co., Ltd., Wuxi, China) was used for measuring piezoelectric constant of polarized ceramic disks. The surface potentials of Ps, Ns, and NPs of KNN were determined by scanning Kelvin probe microscopy (SKPM) (Multimode 8, Bruker, Blaireka, USA). Bicinchoninic acid (BCA) assay (Cwbio, Shanghai, China) was used to determine the protein adsorption amount. The proliferation measurement was quantified using a Cell Counting Kit-8 (CCK-8) assay (Shanghai Beyotime Institute of Biotechnology, Shanghai, China) and Prism 5.0 software (GraphPad software Inc., La Jolla, CA, USA, 2012) was applied to deal with the data. Significance levels were set at ${ }^{* *}<0.01$.

\section{Conclusions}

Biocompatible KNN ceramic with piezoelectric constant of $\sim 93 \mathrm{pC} / \mathrm{N}$ was prepared through adjusting ball-milling time and calcination temperature and was considered to be a promising electro-active biomaterial for tissue implant. Evidence of TG-DTA curves and XRD patterns revealed that the complete solid reaction product with particle size of $0.03-0.3 \mu \mathrm{m}$ could be obtained by ball milling for $8 \mathrm{~h}$ and then calcined at $700{ }^{\circ} \mathrm{C}$ for $2 \mathrm{~h}$. The potentials of positive surfaces (Ps), negative surfaces (Ns) and non-polarized surfaces of $\mathrm{KNN}$ were $171 \pm 9,49 \pm 5$, and $90 \pm 8 \mathrm{mV}$ as evaluated, respectively. Both positive and negative surfaces exhibited enhanced protein adsorption and cell proliferation over non-polarized surfaces, suggesting that role of surface potential on protein adsorption and cells proliferation depended primarily on the presence of charge. KNN ceramics can be used to understand the role of surface potential on cells processes and great potential as an electroactive material in hard tissue regeneration.

Acknowledgments: The authors gratefully acknowledge the National High Technology Research and Development Program of China (863 Program) (Grant No. 2015AA033502), the National Natural Science Foundation of China (Grant No. 51372087, 51541201), the Science and Technology Planning Project of Guangdong Province, China (Grant No. 2014A010105048), the Natural Science Foundation of Guangdong Province (Grant No. 2015A030313493, 2016A030308014), and the State Key Laboratory for Mechanical Behavior of Materials, China (Grant No. 20141607).

Author Contributions: C.N. and J.P. conceived the experiments; G.T. and Z.Y. designed the experiments; W.C. wrote the paper; W.C. and P.Y. revised the paper.

Conflicts of Interest: The authors declare no conflict of interest.

\section{References}

1. Fukada, E.; Yasuda, I. On the piezoelectric effect of bone. J. Phys. Soc. Jpn. 1957, 12, 1158-1162. [CrossRef]

2. Bassett, C.A.; Becker, R.O. Generation of electric potentials by bone in response to mechanical stress. Science 1962, 137, 1063-1064. [CrossRef] [PubMed]

3. Braden, M.; Bairstow, A.; Beider, I.; Ritter, B. Electrical and piezo-electrical properties of dental hard tissues. Nature 1966, 212, 1565-1566. [CrossRef] [PubMed]

4. McElhaney, J.H. The charge distribution on the human femur due to load. J. Bone Jt. Surg. Am. 1967, 49, 1561-1571. [CrossRef]

5. Eiichi, F.; Iwao, Y. Piezoelectric effects in collagen. Jpn. J. Appl. Phys. 1964, 3, 117.

6. Marino, A.A.; Becker, R.O.; Soderholm, S.C. Origin of the piezoelectric effect in bone. Calcif. Tissue Res. 1971, 8, 177-180. [CrossRef] [PubMed]

7. Williams, W.S.; Breger, L. Piezoelectricity in tendon and bone. J. Biomech. 1975, 8, 407-413. [CrossRef]

8. Halperin, C.; Mutchnik, S.; Agronin, A.; Molotskii, M.; Urenski, P.; Salai, M.; Rosenman, G. Piezoelectric effect in human bones studied in nanometer scale. Nano Lett. 2014, 4, 1253-1256. [CrossRef]

9. Minary-Jolandan, M.; Yu, M.F. Uncovering nanoscale electromechanical heterogeneity in the subfibrillar structure of collagen fibrils responsible for the piezoelectricity of bone. ACS Nano 2009, 3, 1859-1863. [CrossRef] [PubMed]

10. Ball, J.P.; Mound, B.A.; Nino, J.C.; Allen, J.B. Biocompatible evaluation of barium titanate foamed ceramic structures for orthopedic applications. J. Biomed. Mater. Res. A 2014, 102, 2089-2095. [CrossRef] [PubMed] 
11. Zhang, X.; Zhang, C.; Lin, Y.; Hu, P.; Shen, Y.; Wang, K.; Meng, S.; Chai, Y.; Dai, X.; Liu, X.; et al. Nanocomposite membranes enhance bone regeneration through restoring physiological electric microenvironment. ACS Nano 2016, 10, 7279-7286. [CrossRef] [PubMed]

12. Dubey, A.K.; Kakimoto, K.; Obata, A.; Kasuga, T. Enhanced polarization of hydroxyapatite using the design concept of functionally graded materials with sodium potassium niobate. RSC Adv. 2014, 4, 24601-24611. [CrossRef]

13. Marino, A.; Arai, S.; Hou, Y.; Sinibaldi, E.; Pellegrino, M.; Chang, Y.T.; Mazzolai, B.; Mattoli, V.; Suzuki, M.; Ciofani, G. Piezoelectric nanoparticle-assisted wireless neuronal stimulation. ACS Nano 2015, 9, 7678-7689. [CrossRef] [PubMed]

14. Horiuchi, N.; Nakaguki, S.; Wada, N.; Nozaki, K.; Nakamura, M.; Nagai, A.; Katayama, K.; Yamashita, K. Polarization-induced surface charges in hydroxyapatite ceramics. J. Appl. Phys. 2014, 116, 014902. [CrossRef]

15. Tarafder, S.; Banerjee, S.; Bandyopadhyay, A.; Bose, S. Electrically polarized biphasic calcium phosphates: Adsorption and release of bovine serum albumin. Langmuir 2010, 26, 16625-16629. [CrossRef] [PubMed]

16. Ohgaki, M.; Kizuki, T.; Katsura, M.; Yamashita, K. Manipulation of selective cell adhesion and growth by surface charges of electrically polarized hydroxyapatite. J. Biomed. Mater. Res. 2001, 57, 366-373. [CrossRef]

17. Bodhak, S.; Bose, S.; Bandyopadhyay, A. Electrically polarized HAp-coated Ti: In vitro bone cell-material interactions. Acta Biomater. 2010, 6, 641-651. [CrossRef] [PubMed]

18. Yamashita, K.; Oikawa, N.; Umegaki, T. Acceleration and deceleration of bone-like crystal growth on ceramic hydroxyapatite by electric poling. Chem. Mater. 1996, 8, 2697-2700. [CrossRef]

19. Bodhak, S.; Bose, S.; Bandyopadhyay, A. Role of surface charge and wettability on early stage mineralization and bone cell-materials interactions of polarized hydroxyapatite. Acta Biomater. 2009, 5, 2178-2188. [CrossRef] [PubMed]

20. Espanol, M.; Mestres, G.; Luxbacher, T.; Dory, J.B.; Ginebra, M.P. Impact of porosity and electrolyte composition on the surface charge of hydroxyapatite biomaterials. ACS Appl. Mater. Interfaces 2016, 8, 908-917. [CrossRef] [PubMed]

21. Nakamura, M.; Yamashita, K. 15 Polarization-mediated modification of hydroxyapatite to improve biological responses. Miner. Scales Biol. Ind. Syst. 2013, 287-306. [CrossRef]

22. Park, J.; Von Recum, A.; Kenner, G.; Kelly, B.; Coffeen, W.; Grether, M. Piezoelectric ceramic implants: A feasibility study. J. Biomed. Mater. Res. 1980, 14, 269-277. [CrossRef] [PubMed]

23. Feng, J.; Yuan, H.; Zhang, X. Promotion of osteogenesis by a piezoelectric biological ceramic. Biomaterials 1997, 18, 1531-1534. [CrossRef]

24. Rubio-Marcos, F.; Ochoa, P.; Fernandez, J.F. Sintering and properties of lead-free $(\mathrm{K}, \mathrm{Na}, \mathrm{Li})(\mathrm{Nb}, \mathrm{Ta}, \mathrm{Sb}) \mathrm{O}_{3}$ ceramics. J. Eur. Ceram. Soc. 2007, 27, 4125-4129. [CrossRef]

25. Rubio-Marcos, F.; Lopez-Juarez, R.; Rojas-Hernandez, R.E.; del Campo, A.; Razo-Perez, N.; Fernandez, J.F. Lead-free piezoceramics: Revealing the role of the rhombohedral-tetragonal phase coexistence in enhancement of the piezoelectric properties. ACS Appl. Mater. Interfaces 2015, 7, 23080-23088. [CrossRef] [PubMed]

26. Wang, K.; Li, J. Analysis of crystallographic evolution in $(\mathrm{Na}, \mathrm{K}) \mathrm{NbO}_{3}$-based lead-free piezoceramics by X-ray diffraction. Appl. Phys. Lett. 2007, 91, 262902. [CrossRef]

27. Wu, L.; Zhang, J.L.; Wang, C.L.; Li, J.C. Influence of compositional ratio K/Na on physical properties in $\left(\mathrm{K}_{x} \mathrm{Na}_{1-x}\right) \mathrm{NbO}_{3}$ ceramics. J. Appl. Phys. 2008, 103, 084116. [CrossRef]

28. Rubio-Marcos, F.; Romero, J.J.; Fernandez, J.F. Effect of the temperature on the synthesis of $\left(\mathrm{K}_{,} \mathrm{Na}\right) \mathrm{NbO}_{3}-$ modified nanoparticles by a solid state reaction route. J. Nanopart. Res. 2010, 12, 2495-2502. [CrossRef]

29. Rubio-Marcos, F.; Romero, J.; Martín-Gonzalez, M.S.; Fernández, J. Effect of stoichiometry and milling processes in the synthesis and the piezoelectric properties of modified KNN nanoparticles by solid state reaction. J. Eur. Ceram. Soc. 2010, 30, 2763-2771. [CrossRef]

30. Cheng, L.Q.; Zhou, J.J.; Wang, K.; Li, J.F.; Wang, Q.M. Influence of ball milling on sintering behavior and electrical properties of ( $\mathrm{Li}, \mathrm{Na}, \mathrm{K}) \mathrm{NbO}_{3}$ lead-free piezoceramics. J. Mater. Sci. 2012, 47, 6908-6914. [CrossRef]

31. Malič, B.; Koruza, J.; Hreščak, J.; Bernard, J.; Wang, K.; Fisher, J.; Benčan, A. Sintering of lead-free piezoelectric sodium potassium niobate ceramics. Materials 2015, 8, 8117-8146. [CrossRef]

32. Zhen, Y.; $\mathrm{Li}$, J. Normal sintering of $(\mathrm{K}, \mathrm{Na}) \mathrm{NbO}_{3}$-based ceramics: Influence of sintering temperature on densification, microstructure, and electrical properties. J. Am. Ceram. Soc. 2006, 89, 3669-3675. [CrossRef]

33. Eiras, J.; Gerbasi, R.; Rosso, J.; Silva, D.; Cótica, L.; Santos, I.; Souza, C.; Lente, M. Compositional design of dielectric, ferroelectric and piezoelectric properties of $(\mathrm{K}, \mathrm{Na}) \mathrm{NbO}_{3}$ and $(\mathrm{Ba}, \mathrm{Na})(\mathrm{Ti}, \mathrm{Nb}) \mathrm{O}_{3}$ based ceramics prepared by different sintering routes. Materials 2016, 9, 179. [CrossRef] 
34. Zeng, J.; Kwok, K.; Chan, $\mathrm{H} . \mathrm{K}_{x} \mathrm{Na}_{1-x} \mathrm{NbO}_{3}$ powder synthesized by molten-salt process. Mater. Lett. 2007, 61, 409-411. [CrossRef]

35. Yang, H.; Lin, Y.; Zhu, J.; Wang, F. An efficient approach for direct synthesis of $\mathrm{K}_{0.5} \mathrm{Na}_{0.5} \mathrm{NbO}_{3}$ powders. Powder Technol. 2009, 196, 233-236. [CrossRef]

36. Rojac, T.; Kosec, M.; Šegedin, P.; Malič, B.; Holc, J. The formation of a carbonato complex during the mechanochemical treatment of a $\mathrm{Na}_{2} \mathrm{CO}_{3}-\mathrm{Nb}_{2} \mathrm{O}_{5}$ mixture. Solid State Ion. 2006, 177, 2987-2995. [CrossRef]

37. Heda, P.K.; Dollimore, D.; Alexander, K.S.; Chen, D.; Law, E.; Bicknell, P. A method of assessing solid state reactivity illustrated by thermal decomposition experiments on sodium bicarbonate. Thermochim. Acta 1995, 255, 255-272. [CrossRef]

38. Zhang, D.; Qin, Z.; Yang, X.; Zhu, H.; Cao, M. Study on synthesis and evolution of sodium potassium niobate ceramic powders by an oxalic acid-based sol-gel method. J. Sol-Gel Sci. Technol. 2011, 57, 31-35. [CrossRef]

39. Wang, K.; Yao, F.; Jo, W.; Gobeljic, D.; Shvartsman, V.V.; Lupascu, D.C.; Li, J.; Rödel, J. Temperature-insensitive $(\mathrm{K}, \mathrm{Na}) \mathrm{NbO}_{3}$-based lead-free piezoactuator ceramics. Adv. Funct. Mater. 2013, 23, 4079-4086. [CrossRef]

40. Bortolani, F.; del Campo, A.; Fernandez, J.F.; Clemens, F.; Rubio-Marcos, F. High strain in (K,Na) $\mathrm{NbO}_{3}$-based lead-free piezoelectric fibers. Chem. Mater. 2014, 26, 3838-3848. [CrossRef]

41. Karageorgiou, V.; Kaplan, D. Porosity of 3D biomaterial scaffolds and osteogenesis. Biomaterials 2005, 26, 5474-5491. [CrossRef] [PubMed]

42. Ge, W.; Li, J.; Viehland, D.; Chang, Y.; Messing, G.L. Electric-field-dependent phase volume fractions and enhanced piezoelectricity near the polymorphic phase boundary of $\left(\mathrm{K}_{0.5} \mathrm{Na}_{0.5}\right)_{1-x} \mathrm{Li}_{x} \mathrm{NbO}_{3}$ textured ceramics. Phys. Rev. B 2011, 83, 224110-224117. [CrossRef]

43. Kilic, M.S.; Bazant, M.Z.; Ajdari, A. Steric effects in the dynamics of electrolytes at large applied voltages. I. Double-layer charging. Phys. Rev. E 2007, 75, 021502. [CrossRef] [PubMed]

44. Bazant, M.Z.; Thornton, K.; Ajdari, A. Diffuse-charge dynamics in electrochemical systems. Phys. Rev. E 2004, 70, 021506. [CrossRef] [PubMed]

45. Carville, N.C.; Collins, L.; Manzo, M.; Gallo, K.; Lukasz, B.I.; McKayed, K.K.; Simpson, J.C.; Rodriguez, B.J. Biocompatibility of ferroelectric lithium niobate and the influence of polarization charge on osteoblast proliferation and function. J. Biomed. Mater. Res. A 2015, 103, 2540-2548. [CrossRef] [PubMed]

46. Lehnert, M.; Gorbahn, M.; Rosin, C.; Klein, M.; Koper, I.; Al-Nawas, B.; Knoll, W.; Veith, M. Adsorption and conformation behavior of biotinylated fibronectin on streptavidin-modified $\mathrm{TiO}_{X}$ surfaces studied by SPR and AFM. Langmuir 2011, 27, 7743-7751. [CrossRef] [PubMed]

47. Rapuano, B.E.; MacDonald, D.E. Surface oxide net charge of a titanium alloy modulation of fibronectinactivated attachment and spreading of osteogenic cells. Colloid Surf. B 2011, 82, 95-103. [CrossRef] [PubMed]

48. Keselowsky, B.G.; Collard, D.M.; Garcia, A.J. Surface chemistry modulates fibronectin conformation and directs integrin binding and specificity to control cell adhesion. J. Biomed. Mater. Res. A 2003, 66, 247-259. [CrossRef] [PubMed]

49. Pernodet, N.; Rafailovich, M.; Sokolov, J.; Xu, D.; Yang, N.L.; McLeod, K. Fibronectin fibrillogenesis on sulfonated polystyrene surfaces. J. Biomed. Mater. Res. A 2003, 64, 684-692. [CrossRef] [PubMed]

50. Hartvig, R.A.; van de Weert, M.; Østergaard, J.; Jorgensen, L.; Jensen, H. Protein adsorption at charged surfaces: The role of electrostatic interactions and interfacial charge regulation. Langmuir 2011, 27, 2634-2643. [CrossRef] [PubMed]

51. Tan, F.; Xu, X.D.; Deng, T.; Yin, M.; Zhang, X.Z.; Wang, J.W. Fabrication of positively charged poly(ethylene glycol)-diacrylate hydrogel as a bone tissue engineering scaffold. Biomed. Mater. 2012, 7, 1-10. [CrossRef] [PubMed]

52. Wilson, C.J.; Clegg, R.E.; Leavesley, D.I.; Pearcy, M.J. Mediation of biomaterial-cell interactions by adsorbed proteins: A review. Tissue Eng. 2005, 11, 1-18. [CrossRef] [PubMed]

53. Yoshida-Noro, C.; Suzuki, N.; Takeichi, M. Molecular nature of the calcium-dependent cell-cell adhesion system in mouse teratocarcinoma and embryonic cells studied with a monoclonal antibody. Dev. Biol. 1984, 101, 19-27. [CrossRef]

54. Chen, J.H.; Hwang, B.H.; Hsu, T.C.; Lu, H.Y. Domain switching of barium titanate ceramics induced by surface grinding. Mater. Chem. Phys. 2005, 91, 67-72. [CrossRef]

(C) 2017 by the authors. Licensee MDPI, Basel, Switzerland. This article is an open access article distributed under the terms and conditions of the Creative Commons Attribution (CC BY) license (http:/ / creativecommons.org/licenses/by/4.0/). 